$\begin{array}{llll}\text { Pediat. Res. 1: 116-121 (1967) } & \begin{array}{l}\text { Leukemia } \\ \text { carbohydrate metabolism } \\ \text { lactic dehydrogenase }\end{array} & \begin{array}{l}\text { glucosc-6-phosphate } \\ \text { dehydrogenase } \\ \text { adenosine triphosphatase } \\ \text { fructose-1,6-diphosphatase pyrophosphatase }\end{array} & \begin{array}{l}\text { liver } \\ \text { glucose-6-phosphatase } \\ \text { glycosen }\end{array}\end{array}$

\title{
Liver Glucose-6-Phosphatase and Carbohydrate Metabolism in Childhood Leukemia
}

\author{
P.J. Collipp, J. R. Patrick, G.S. Gilchrist, G.N. Donnell and C. Brubaker \\ Childrens Hospital of Los Angeles and the University of Southern California School of Medicine, \\ Department of Pediatrics, and Maimonides Hospital of Brooklyn, N.Y., USA
}

\section{Extract}

Triplicate determinations of glucose-6-phosphatase activity in the $37,000 \times \mathrm{g}$ fraction of human liver homogenates were made. Table I summarizes the results from 100 consecutive autopsies. Enzyme activity for 78 nonleukemic children was $95 \pm 66$ ( $1 \mathrm{SD}$ ), and for 22 leukemic children was $17 \pm 12$ (1 SD) $(\mathrm{p}<0.001)$. In the leukemic group there was no relation between the glucose-6-phosphatase activity with antileukemic drug therapy, the white blood cell count and the duration of the disease prior to death. The quantity of leukemic infiltrate in these livers varied, but there was no correlation between the extent of infiltration and enzyme activity. Several livers from leukemic children had no infiltrate and still had low glucose-6-phosphatase activities. One infant with liver glycogen disease had the expected reduction in glucose-6-phosphatase activity. A few children with other diseases (histiocytosis X, lupus erythematosis, aplastic anemia and retinoblastoma) had low enzyme activity in the liver.

The time interval, 2-24 hours, between death and autopsy had no demonstrable effect on enzyme activity. Enzyme activity in nonleukemic liver diminished $5 \%$ /day after storage up to 10 days and did not change significantly in leukemic livers. When $10 \%$ liver homogenates, or the $37,000 \times \mathrm{g}$ fraction, was stored for 4 weeks at $-20^{\circ} \mathrm{C}$ the percent of the original activity at 1, 2, 3 and 4 weeks was $70 \%, 65 \%, 53 \%$ and $53 \%$ respectively.

A gradual, but significant, decline in human liver glucose-6-phosphatase activity occurs between birth and old age (fig. 2).

Several potential inhibitors of enzyme activity were tested. The results are summarized in table II. Inhibition by p-chloromercuribenzoate and copper, and a lack of activation by magnesium are characteristic of this enzyme. Inhibition by sodium amytal was determined at $\mathrm{pH} 7.5$ for both the control and the amytal-containing assays because of the poor solubility of amytal at $\mathrm{pH} 6.5$.

Table III summarizes the results of glucagon tolerance tests performed on leukemic children ( 7 in remission, 8 in relapse). It is apparent that the blood sugar rose higher at 15 and 30 minutes in the remission group than in the relapse group. The increase in both groups would probably be considered within the normal range, but the difference between them was significant $(P<0.05)$. Lactate concentration was determined on each serum specimen and did not vary in response to glucagon, but was significantly higher in relapse than in remission. The means for the relapse and remission groups were significantly different $(\mathrm{P}<0.001)$ at each time interval. Serum lactate was determined on one leukemic child 4 hours before death and was $150 \mathrm{meq} / \mathrm{L}$.

Other enzyme activities which were determined on 8 leukemic and 8 nonleukemic livers after storage at $-20^{\circ} \mathrm{C}$ an average of 10 (controls) and 15 (leukemics) weeks are summarized in table IV. 
Two fresh leukemic and two nonleukemic livers were also assayed for each activity. The average of these assays were (leukemic, nonleukemic): lactic dehydrogenase- $0.44,0.40$; glucose-6-phosphate dehydrogenase- 17.0, 8.5; adenosine triphosphatase 6.8, 14.0; inorganic pyrophosphatase 14, 33; fructose-1, 6-diphosphatase 6.0, 9.0. Four of the leukemic livers had no detectable lactic dehydrogenase activity (below 0.02 ), while the other four had activities comparable to that found in the nonleukemic livers. These data may be summarized as indicating that liver from children with leukemia had reduced glucose-6-phosphatase, inorganic pyrophosphatase, and sometimes had reduced lactic dehydrogenase activity. Glucose-6-phosphate dehydrogenase was increased 2-3 fold. Adenosine triphosphatase, fructose-1, 6-diphosphatase and glycogen were present in normal amounts.

\section{Speculation}

Altered carbohydrate metabolism in children with terminal leukemia may have clinical manifestations (hypoglycemia and lactic acidosis) which are not commonly suspected. The possibility exists that these metabolic changes are part of the leukemic process rather than a result of it and relate to the basic pathology of neoplasma.

\section{Introduction}

After our 1st report [5] indicating that liver glucose-6phosphatase was abnormally low in children who died of acute lymphatic leukemia, 3 questions necded to be answered.

1. Was this a unique finding in leukemia, or was it also found in other fatal diseases? 2. Was this a terminal event or was liver glucosc-6-phosphatase activity reduced carlier in lcukemia? 3. What associated enzymatic abnormalities were present? This report summarizes data suggesting partial answers to these questions.

\section{Methods}

Glucose-6-phosphatase was assayed by the method described by Swanson [14] in which liver homogenate and glucose-6-phosphate were incubated at $\mathrm{pH} 6.5$ in $0.02 \mathrm{M}$ maleate buffer for $15 \mathrm{~min}$ at $37^{\circ} \mathrm{C}$. Activity was then calculated as $m$ /moles phosphorus released from glucose-6-phosphate/mg of protein/min. Duplicate assays of all leukemic and most of the non-lcukemic livers indicated that the method gave reproducible results. $10 \%$ liver homogenates were prepared in $0.12 \mathrm{M} \mathrm{KCl}$ at $0^{\circ} \mathrm{C}$ by homogenization at $800 \mathrm{rpm}$ for $4-5 \mathrm{~min}$ with a glass-teflon homogenizer. This homogenate was divided into 3 fractions by successive centrifugation at $600 \times \mathrm{g}$ for $10 \mathrm{~min}, 37,000 \times \mathrm{g}$ for $30 \mathrm{~min}$, and a final supernatant. Thesc 2 residues were resuspended in 0.12 $\mathrm{M} \mathrm{KCl}$ at a concentration of $10-15 \mathrm{mg} / \mathrm{ml}$, and were kept at $0^{\circ} \mathrm{C}$ until the assay. Each assay mixture contained $0.1 \mathrm{ml}$ of liver homogenate, $0.3 \mathrm{ml}$ of maleate buffer, and $0.1 \mathrm{ml}$ of glucose-6-phosphate, as described by Swanson [14]. Protcin and phosphorus were determined by the methods of Lowry et al. [10] and FisKe and Subbarow [6].

Each liver specimen was obtained at autopsy and the interval between death and autopsy was recorded. Drug therapy was also recorded for each patient. The clinical and pathologic diagnoses were reviewed and only diagnoses confirmed by pathological examination are reported. When the assay was not run immediately on the fresh liver specimen, it was stored at $-20^{\circ} \mathrm{C}$ until the assay. Remission and relapse in these leukemic children was determined clinically and confirmed by bone marrow examination in each child.

Glucagon tolerance tests were run using $0.1 \mathrm{mg}$ glucagon/kg body weight injected IV. Glucose and lactate were determined by standard methods $[1,11]$. The liver homogenates were also assayed for adenosine triphosphatase [8] and inorganic pyrophosphatase [13] activity. Supernatant fractions obtained by centrifuging liver homogenate at $100,000 \times \mathrm{g}$ for $30 \mathrm{~min}$ in a Spinco Model L Ultracentrifuge, were assayed for fructose-1,6-diphosphatase [17], lactic dehydrogenase [17], and glucose-6-phosphate dehydrogenase [7]. Glycogen was determined using the anthrone method described by VAN DER VIES [16].

\section{Results}

Triplicate assays of glucose-6-phosphatase in a human liver homogenate were run at $37^{\circ} \mathrm{C}$ and $\mathrm{pH} 6.5$ for 0 , 5,10 and $15 \mathrm{~min}$ incubation times. The inorganic phosphorus liberated from glucose-6-phosphate by a constant amount of liver homogenate was $0,1.3,2.1$ 
and $3.0 \mu$ moles, respectively. The $\mathrm{pH}$ optimum of the $37,000 \times \mathrm{g}$ fraction of liver homogenate was evaluated by substituting $0.1 \mathrm{M}$ buffers for the maleate buffer in the assay mixture. Duplicate assays ( $15 \mathrm{~min}$ incubation at $37^{\circ} \mathrm{C}$ ) at $\mathrm{pH} 4.5,5.0,5.5$ (acetate), 6.0, 6.5, 7.0 (maleate), 8 and 9 (tris-Cl) were run and the glucose6-phosphatase activity (m/moles $\mathrm{P} / \mathrm{mg}$ protein/min) was $6,8,144,163,166,156,100$ and 39 , respectively. Duplicatc assays at $20^{\circ} \mathrm{C}, 30^{\circ} \mathrm{C}, 37^{\circ} \mathrm{C}, 42^{\circ} \mathrm{C}, 50^{\circ} \mathrm{C}$ and $60^{\circ} \mathrm{C}$ were run at $\mathrm{pH} 6.5$ using the $37,000 \times \mathrm{g}$ fraction of liver homogenate and the activities were 33,117 , $169,172,108$ and 0 , respectively.

Table I summarizes the glucose-6-phosphatase activity in the $37,000 \times \mathrm{g}$ fraction of liver homogenate from 100 consecutive autopsies at the Los Angeles Children's Hospital. Results are grouped into diagnostic categories where possible. Enzyme activity for 78 non-

Table I. Human liver glucose-6-phosphate activity ( $\mathrm{m} / \mathrm{moles} \mathrm{P} / \mathrm{mg}$ protein $/ \mathrm{min}$ )

\begin{tabular}{|c|c|c|c|c|}
\hline Diagnosis & & $\begin{array}{l}\text { Number } \\
\text { of cases }\end{array}$ & Range & Mean \\
\hline \multicolumn{5}{|l|}{ Leukemia } \\
\hline lymphatic . . . . & & 15 & $1-45$ & 19 \\
\hline myelogenous . . . . & 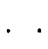 & 4 & $0-19$ & 8 \\
\hline $\begin{array}{l}\text { undifferentiated . . } \\
\text { Nonleukemia }\end{array}$ & .. & 3 & $13-26$ & 21 \\
\hline congenital heart discase & & 25 & $0-239$ & 114 \\
\hline pncumonia. . . . . & . & 8 & $6-182$ & 70 \\
\hline uremia . . . . . . & . & 8 & $6-179$ & 100 \\
\hline $\begin{array}{l}\text { meningitis and scpsis } \\
\text { anemia }\end{array}$ & $\cdot \cdot$ & 8 & $50-169$ & 100 \\
\hline aplastic . . . . . & . & 3 & $8-26$ & 18 \\
\hline $\begin{array}{l}\text { Cooley's . . . . · } \\
\text { hypoplastic with }\end{array}$ & . . & 1 & 28 & 28 \\
\hline diabetes mellitus & . . & 2 & $3-114$ & 60 \\
\hline \multicolumn{5}{|l|}{ neoplasms } \\
\hline lymphosarcoma & . . & 1 & 79 & 79 \\
\hline neuroblastoma . . & . . & 2 & $78-82$ & 80 \\
\hline retinoblastoma . . & . . & 1 & 24 & 24 \\
\hline pituitary carcinoma & . . & 1 & 100 & 100 \\
\hline sarcoma & & 1 & 180 & 180 \\
\hline prematurity . . . . & . . & 2 & $229-294$ & 260 \\
\hline $\begin{array}{l}\text { tracheoesophageal fistu } \\
\text { imperforate anus. }\end{array}$ & & 2 & $96-118$ & 107 \\
\hline \multicolumn{5}{|c|}{ Hirschsprung's disease and } \\
\hline bowel obstructions & . . & 2 & $96-179$ & 137 \\
\hline CNS hemorrhage . & . & 4 & $12-187$ & 70 \\
\hline cystic fibrosis . . . . & . & 2 & $32-150$ & 91 \\
\hline histiocytosis . . . . & . . & 2 & $11-38$ & 24 \\
\hline glycogen storage disease & se . & 1 & 0 & 0 \\
\hline lupus erythematosis . & . & 1 & 20 & 20 \\
\hline gastroenteritis!. . . & & 1 & 121 & 121 \\
\hline
\end{tabular}

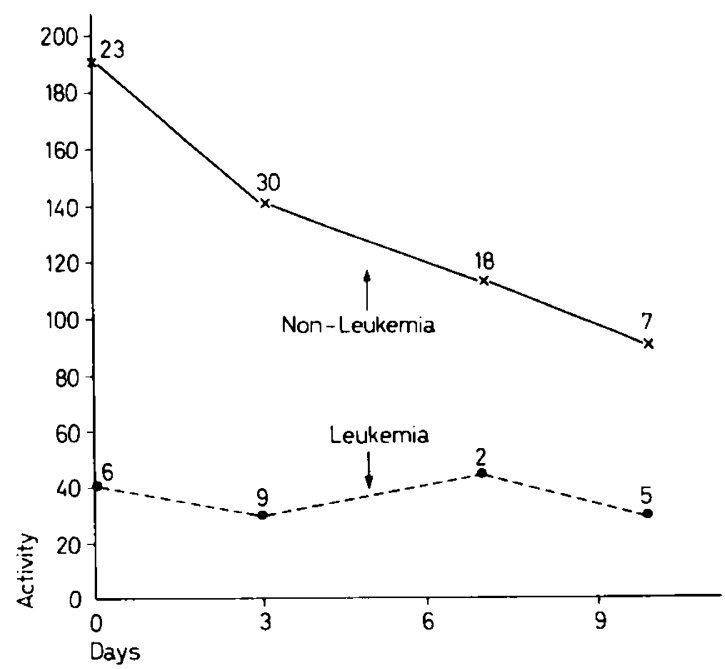

Fig. 1. Avcrage liver glucose-6-phosphatase activity ( $\mathrm{m} /$ moles $\mathrm{P} / \mathrm{mg}$ protein $/ \mathrm{min}$ ) is compared to the time interval between autopsy and assay. Liver specimens were stored at $-20^{\circ} \mathrm{C}$ for $0,1-3,4-7$, and 8-12 days. The number of assays in each time interval is indicated. The difference between leukemia and nonleukemia is significant, $\mathrm{P}=0.01$, at each time interval.

leukemic children was $95 \pm 66$ ( $1 \mathrm{SD}$ ), and for 22 leukemic children was $17 \pm 12$ (1 SD). The difference between these two means was significant $(P<0.001)$. Within the leukemic group, attempts were made to correlate the glucose-6-phosphatase activity with the antileukemic drug therapy, the white blood cell count, and the duration of the leukemia prior to death. No relationship between these 3 variables and the activity was found. Two children with leukemia had received no antileukemia drugs, and had reduced enzyme activity $(11,37)$. The quantity of leukemic infiltrate in these livers varied, but there was no correlation between the extent of infiltration and the activity. Several livers from leukemic children had no infiltrate and still had low glucose-6-phosphatase activities. One infant with glycogen storage discase had the expected reduction in liver glucose-6-phosphatase. A few children with other diseases were found to have low liver glucose-6-phosphatase (histiocytosis X, lupus erythematosis, aplastic anemia and retinoblastoma).

The time interval, 2-24 hours between death and autopsy had no demonstrable effect on cnzyme activity. This time interval was recorded for each case, and the mean enzyme activity did not vary when the interval was $0-6$ hours ( 31 cases), 7-12 hours (29 cases), 13-18 hours (25 cases), and 19-24 hours (15 cases). Most assays were run promptly, and in others the liver was stored at $-20^{\circ} \mathrm{C}$ as indicated in figure 1. Enzyme activity diminished $5 \%$ /day up to 10 days in nonleu- 
kemic liver, and did not significantly change in the leukemic livers. When $10 \%$ liver homogenate, or the $37,000 \times \mathrm{g}$ fraction, was stored for 4 weeks at $-20^{\circ} \mathrm{C}$ the $\%$ of the original activity at 1,2, 3 and 4 weeks was $70 \%, 65 \%, 53 \%$ and $53 \%$, respectively.

The effect of age on the glucose-6-phosphatase activity is indicated in figure 2. A gradual, but significant, decline in human liver glucose-6-phosphatase activity occurs between birth and old age.

Several potential inhibitors were tested and the results are summarized in table II. Inhibition by p-chloromercuribenzoate and copper, and the lack of activation by magnesium are characteristic of this enzyme. Inhibition by sodium amytal was determined at $\mathrm{pH}$ 7.5 for both the control and the amytal-containing assays because of the poor solubility of amytal at $\mathrm{pH}$ 6.5. Amytal is a known inhibitor of DPNH oxidase activity and the fractionation reported by Moury and CRANE [12] of electron transport components in liver suggested their presence in the $37,000 \times \mathrm{g}$ fraction. Novobiocin is known to inhibit the microsomal en-

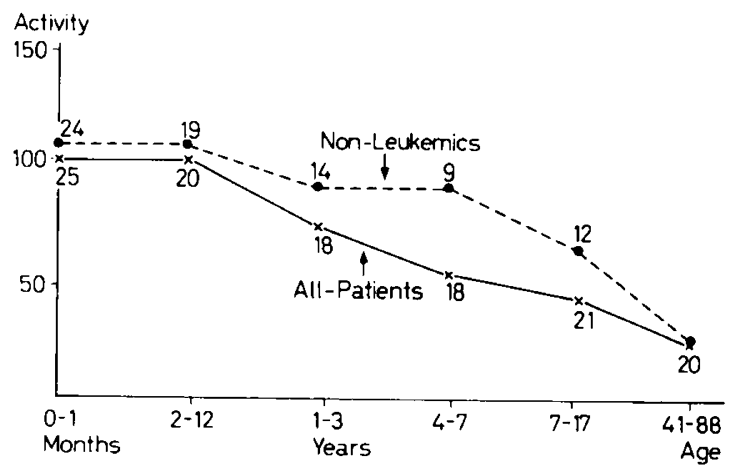

Fig. 2. Average liver glucose-6-phosphatase activity ( $\mathrm{m} \mu \mathrm{moles} \mathrm{P} / \mathrm{mg}$ protein $/ \mathrm{min}$ ) is compared to age. The number of assays in each age interval is indicated. The difference between $0-1$ month and $41-88$ years was significant $(P<0.01)$. zyme glucuronyl transferase [9], and its inhibition of glucose-6-phosphatase, another microsomal enzyme raised the possibility of a structural similarity between these two enzymes. Chloramphenicol, a drug which can lower glucose-6-phosphatase activity when administered to ducks [4], was not an inhibitor at $10^{-4} \mathrm{M}$.

Table III summarizes the results of glucagon tolerance tests performed on leukemic children ( 7 in remission, 8 in relapse). It is apparent that the blood sugar rose higher at 15 and $30 \mathrm{~min}$ in the remission group than in the relapse group. The increase in both groups would probably be considered within the normal range, but the difference between them was significant $(P<0.05)$. Lactate concentration was determined on each serum specimen and did not vary in response to glucagon, but was significantly higher in relapse than in remission. The means for the relapse and remission groups were significantly different $(P<0.001)$ at each time interval. Serum lactate was determined on one leukemic child 4 hours before death and was 150 $\mathrm{mEq} / 1$.

Table II. Inhibitor studies of human glucose-6-phosphatase

\begin{tabular}{|c|c|c|}
\hline Inhibitor & $\begin{array}{l}\text { Concentration } \\
(\mathrm{M})\end{array}$ & $\begin{array}{l}\% \text { of } \\
\text { Control }\end{array}$ \\
\hline $\mathrm{CuCl}_{2}$ & 0.01 & 4 \\
\hline $\mathrm{MgCl}_{2} \cdot$. . . . . . & 0.01 & 95 \\
\hline Sodium amytal . & 0.01 & 35 \\
\hline p-chloromercuribenzoate & 0.002 & 6 \\
\hline p-chloromercuribenzoate & 0.0002 & 78 \\
\hline Novobiocin . . . . . . & 0.002 & 53 \\
\hline Novobiocin . & 0.0002 & 90 \\
\hline Chloramphenicol . . . & 0.0001 & 102 \\
\hline Chloramphenicol . . . & 0.00001 & 96 \\
\hline
\end{tabular}

1 The data represent the average of two separate experiments with each inhibitor.

Table III. Glucagon tolerance tests ${ }^{1}$

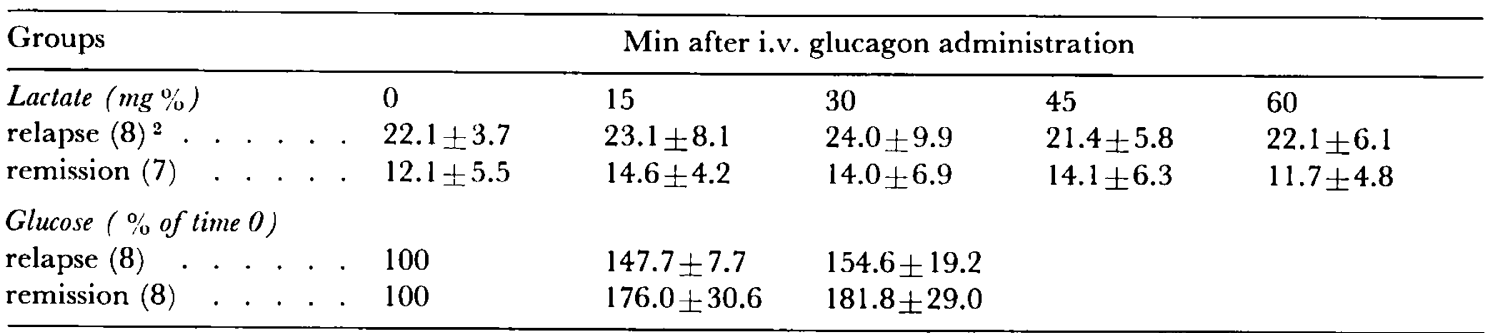

1 Data represent the mean \pm 1 standard deviation. Differences between remission and relapse for glucose and lactate at all time intervals were significant $(\mathbf{P}<0.001)$.

2 The number of patients is indicated in parentheses. 
Table IV. Summary of other liver enzyme activities

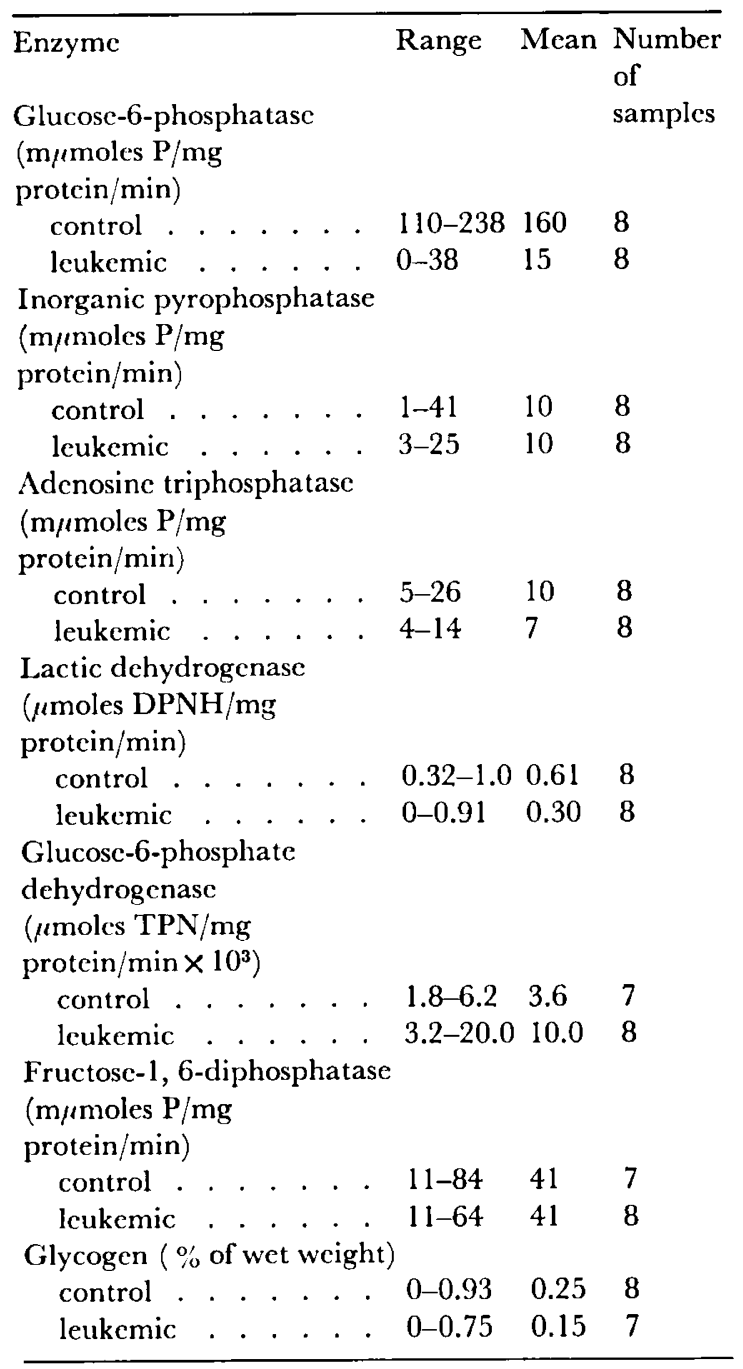

Table IV summarizes the results of other enzyme activities which were determined on 8 leukemic and 8 nonleukemic livers. Glucose-6-phosphatase activity was determined on the day of the autopsy. The other measurements were made on liver specimens which had been stored at $-20^{\circ} \mathrm{C}$ an average of 10 (controls) and 15 (leukemics) weeks. Two fresh leukemic and two nonleukemic livers were also assayed for cach activity. The average of these assays were (leukemic, nonleukemic): lactic dehydrogenase $0.44,0.40$; glucose-6phosphate dehydrogenase 17.0, 8.5; adenosine triphosphatase 6.8, 14.0; inorganic pyrophosphatase 14, 33; fructose-1,6-diphosphatase- 6.0, 9.0. Four of the leukemic livers summarized in table IV had no detectable lactic dehydrogenase (below 0.02), while the other four had activities comparable to the nonleukemic livers. These data may be summarized as indicating that liver from children with leukemia had reduced glucose-6-phosphatase, inorganic pyrophosphatase, and sometimes had reduced lactic dehydrogenase. Glucose-6-phosphate dehydrogenase was increased 2-3 fold. Adenosine triphosphatase, fructose1,6-diphosphatase and glycogen were present in normal amounts.

\section{Discussion}

Liver glucose-6-phosphatase assays for this study were all done at $\mathrm{pH} 6.5$ using the residue from liver homogenate that sediments between $600 \times \mathrm{g}$ and $37,000 \times \mathrm{g}$. This procedure has the advantage of providing a 2-3 fold purification of the activity, making the assay more sensitive, and also tends to reduce errors caused by soluble non-specific phosphatases.

These data indicate that 22 consecutive autopsy liver specimens from children with leukemia were deficient in glucose-6-phosphatase activity. Among nonleukemics, aplastic anemia (3), histiocytosis (2), glycogen storage disease (1), lupus erythematosis (1) and occasional patients with heart disease, uremia, and pneumonia also had reduced liver glucose-6-phosphatase activity. Insufficient patients were analyzed for most of these diseases to know how commonly it occurs in them.

The time when liver glucose-6-phosphatase becomes reduced during the course of childhood leukemia has not becn established. It was not possible to obtain biopsy liver specimens from leukemic children.

Data from the glucagon tolerance tests indicate that this enzyme activity may be reduced at the time of relapse. Reduction of liver glycogen stores and reduction of other glycogenolytic enzyme activities could also account for these data.

The other enzymes which were studied in this report indicated that liver lactic dehydrogenase was markedly reduced in some leukemics. When correlated with the finding by BiERMAN et al. [3] that serum lactic dehydrogenase is commonly elevated in leukemia, it would seem to be reasonable to suggest that part of the increased serum lactic dehydrogenase may have come from the liver. Increased liver glucose-6-phosphate dehydrogenase activity was found in the children with leukemia. One possible mechanism for this could come from the reduced glucose-6-phosphatase activity. It is possible that increased intracellular glucose-6-phosphate may induce enzymes like glucose-6-phosphate dehydrogenase for which it is the substrate.

Elevated serum lactate concentration in lcukemic children during relapse, and much greater increases just prior to death, is similar to the situation in leukemic 
chickens [2]. During the 24 hours prior to death, chickens infected with myeloblastosis virus developed a sudden reduction in blood sugar concentration. TRANQUADA [15] recently reviewed 71 reported cases of lactic acidosis, which included 9 leukemics and many patients with liver diseases. There were also patients with heart and kidney discases. The data in the present study would suggest that lactic acidosis may be very common in leukemia, and relatively rare in heart and kidney discase.

The cause for liver glucose-6-phosphatase reduction in leukemia is unknown at present, but does not seem to be related to the drug therapy. Since leukemic children frequently die of bacterial sepsis, the effect of sepsis on liver glucosc-6-phosphatase has been evaluated in animals [4]. Prolonged (6 days) sepsis with S. aureus was noted to significantly reduce rat liver glucose-6-phosphatase activity. There was no significant change in activity after a single lethal i.p. injection of $S$. aureus, or after $\mathbf{6}$ days sepsis with Pseudomonas. Therefore, bacterial sepsis may be one factor contributing to the reduced liver glucose-6-phosphatase in leukemia. The magnitude of this effect varies with the duration of the sepsis, and with the infecting organism. The 8 children who dicd of sepsis and meningitis had normal liver glucose-6-phosphatase, however.

\section{Summary}

Liver glucose-6-phosphatase activity was abnormally low in every child in which it was measured $(22$ children) who died of leukemia. This enzyme activity was also reduced in children who died of aplastic anemia, and occasionally in other discases. Aging was associated with a significant decline in liver glucose-6-phosphatase activity. Assays on 8 leukemic and 8 control livers indicated that lactic dehydrogenase was also reduced in leukcmia, and that glucose-6-phosphate dehydrogenase was elevated. Glucagon tolerance tests indicated that leukemic children in relapse have significantly less elevation in blood glucose than those in remission. Serum lactate concentration was significantly higher when the leukemic child was in relapse than in remission.

\section{References and $\mathcal{N o t e s}$}

1. Barker, S. B. and Stmmerson, W.H.: The colorimetric determination of lactic acid in biological material. J.biol. Chem. 138: 535-554 (1941).

2. Becker, C.; Beaudreau, G.S. and Beard, J.W.: Glucose and lactate concentrations in plasma of chickens with myeloblastosis and erythroblastosis. J.nat. Cancer Inst. 24: 387-394 (1960).
3. Bierman, H.R.; Hill, B. R.; Reiniardt, L. and EMORy, E.: Correlation of serum lactic dehydrogenase activity with the clinical status of patients with cancer, lymphomas and leukemias. Cancer Res. 17: 660-667 (1957).

4. Collipp, P.J. : unpublished observations.

5. Collipp, P.J.; Kaplan, S.A. and Patrick, J.R.: Reduced liver glucose-6-phosphatase in human leukemia. Proc.Soc. exp. Biol. (N.Y.) 118: 42-43 (1965).

6. Fiske, C.H. and Subbarow, Y.: The colorimetric determination of phosphorus. J.biol. Chem. 66: 375-400 (1925).

7. Glock, G.E. and Maclean, P.: A preliminary investigation of the hormonal control of the hexose monophosphate oxidative pathway. Biochem.J. 61: 390-397 (1955).

8. Kielley, W.W.: in Methods in Enzymology; ed. Colowick, S.P. and KaPlan, N.O.; vol. 2, p. 593 (Academic Press, New York 1955).

9. Lokietz, H.; Dowben, R.M. and HsiA, D.Y.: Studics on the effect of novobiocin on glucuronyl transferase. Pediatrics 32: 47-51 (1963).

10. Lowry, O.H.; Rosebrough, M.J.; FArr, A.L. and Randall, R.J.: Protein measurement with the folin phenol reagent. J.biol.Chem. 193: 265-275 (1951).

11. Marks, V.: An improved glucose oxidase method for determining blood, C.S.F., and urine glucose levels. Clin. chim. Acta 4: 395-400 (1959).

12. Moury, D.N. and Crane, F.L.: Identification of an electron transfer particle from rat liver. Biochem. Biophys. Res. Comm. 15: 442-447 (1964).

13. Nordlie, R. G. and Arion, W.J.: Evidence for the common identity of glucose-6-phosphatase, inorganic pyrophosphatase and pyrophosphatc-glucose phosphotransferasc. J. biol. Chem. 239: 1680-1685 (1964).

14. Swanson, M.A.: in Methods in Enzymology; ed, Colowick, S.P. and Kaplan, N.O.; vol.2, p. 541 (Academic Press, New York 1955).

15. Tranquada, R.E.: Lactic acidosis. Calif. Med. 101: 450-461 (1964).

16. VAN DER Vies, J.: Two methods for the determination of glycogen in liver. Biochem.J. 57: 410-416 (1954).

17. Weber, G. and Cantero, A.: Fructose-1, 6-diphosphatase and lactic dehydrogenase activity in hepatoma and in control human and animal tissues. Cancer Res. 19: 763-768 (1959).

18. Mr. Ruben Frollo and Miss Betty Knoch provided technical assistance, and Mr. Michael Williamson statistically analyzed the data.

19. This rescarch was supported by USPHS Grant No. HD-01501-01. 